Vol. 5, No. 1, 2019

\author{
Andrii Markovskyi
}

\title{
TRANSFORMATION OF PARADIGM IN CONTEST FOR THE DEVELOPMENT OF KYIV CITY CENTER IN THE 1930-1940s
}

\author{
PhD architecture, \\ Scientific Secretary of the Department of Plastic Arts Synthesis at \\ National Academy of Arts of Ukraine \\ 20, Bulvarno-Kudrjavska Str., Kyiv, 01054 Ukraine \\ andrii_markovskyi@ukr.net
}

Received: 12.05.2019/Revised: 18.06.2019/Accepted: 24.07.2019

(C) Markovskyi A., 2019

Abstract. The main tendencies of transformation of the city's architectural and artistic field in connection with social and political changes caused by the World War II have been explored on the example of two key contests for the development of Kyiv city center (Government quarter in 1934-1935 and Khreshchatyk in 1944).

Key words: architecture of Kyiv, contest, Government quarter, Khreshchatyk, transformation of paradigms.

Starting with the establishment of a vertical control over art and culture that was finally crystallized in the USSR in the mid-1930s, and by the mid-1950s, Soviet architecture as a whole and the architecture of Kyiv, as the capital of the second in terms of the republic's significance, were primarily ideological and declarative, representative character. The main task delegated to the ruling elites was to legitimize the new social order and establish its power by creating an appropriate mythological field, which, like any invented tradition (according to Hobsbawm), was emphasized by historical reminiscences: "In fact, where possible, they [invented traditions] normally attempt to establish continuity with a suitable historic past" [1, p. 1].

However, the conditions prevailing within the relevant cultural and artistic environment were not homogeneous, substantially changing in time under the influence of a powerful external factor - the World War II. Conditionally breaking the corresponding field into "before" and "after", the military conflict has made powerful deformations in the global perception of the development vectors of Kyiv architecture, which we will talk about in this article.

The architectural and artistic life in the capital of the Ukrainian SSR in the corresponding period was full of vivid events, from which we distinguish two main, most characteristic and representative, both in terms of scope and meaning, and by the galaxy of the represented masters: two contests for the development of the Governmental quarter in 1934-1935 - "before"; and the reconstruction of Khreshchatyk in 1944 - "after".

The selection of competitive works is not accidental: in our opinion, conceptual projects are most presentable both in terms of manifestation of the ideological and declarative requirements of the customer, power elites, and the true creative idea of the architect. It is precisely in pure "paper" projects that both the declarative and the ideological and artistic component can be traced without the subsequent changes and layers that arise during implementation, often lead to impoverishment and distortion of the original idea due to various structural and financial obstacles. 
Both contests were well covered both in the professional and in the widely popular media. Specific literature sources can be divided into two main groups: 1) Eyewitnesses and contemporaries of relevant events; 2) Later researchers from the Soviet and post-Soviet periods. Within the first group we should especially note the architect O. G. Molokin, who was the direct participant of the first contest and gave its detailed description in the article "Designing the Government Center of the Ukrainian SSR in Kyiv" [2]; and researcher M. P. Bilinkin, who described the second contest in the article "Main Highway of Kyiv: designing the Khreshchatyk" [3]. Almost all participants of the events touched them in their memoirs. They have not been left out from the attention of a large number of Soviet and modern researchers from Yu. S. Aseyev, S. K. Kilesso, A. V. Ikonnikov, M. I. Grechini to B. L. Yerofalov-Pylypchak, B. S. Cherkes, V. E. Alyoshin, D. S. Khmelnytsky and others. We, as the author, have also devoted more than a dozen articles to this topic.

However, the outstanding importance, scale, complex and multifaceted ideological, political, social and artistic factors, a galaxy of invited masters and the fundamental issues posed by questions still inspire researchers to discover more and more facets of relevant events. In this article, we will analyze the transformations that took place in the specified architectural artistic field and try to interpolate the revealed trends and patterns on the general processes that took place in the construction life of Kyiv in the second half of the twentieth century.

Let us start with the identification of identities: both contests were initiated at the highest level of political elites, both of them invited the best architects of the country, both of them were supposed to change the historical center of Kyiv in a key way. Both almost did not touch (and according to D. S. Khmelnytsky, directly ignored) the surrounding residential development, highlighting only key administrative and public facilities as meaningful. However, the tasks and strategies for their solution had a number of fundamental differences, dictated by the transformation of the social and political paradigm.

The first contest for the development of the Governmental Quarter was initiated by the decision of the Central Committee of the Communist Party (b) of Ukraine [4] after returning the capital from Kharkov to Kiev in 1934, when the question arose about the creation of a new center for the governing apparatus of the Ukrainian SSR. A massive redevelopment was planned: the capital of Soviet Ukraine had to be transformed from "priestly-philistine <...> into the advanced industrial center", according to the head of the Kyiv city council R. R. Petrushansky. It was planned to lay new transport arteries, change the zoning of the territory and, unfortunately, the demolition of numerous religious buildings. The new government quarter concentrating a number of administrative buildings, primarily the houses of the RNK and the Central Committee of the CPU (B) U, grouped around a large square for the ceremonial parades and demonstrations had to become the key core $[5$, p. 1].

The three rounds of the contest were attended by brigades led by:

Round I: Y. A. Steinberg, F. F. Oliynyk, V. G. Zabolotny, O. G. Molokin, V. K. Trotsenko, V. O. and A. O. Vesnin [2, p. 12];;

Round II: I. O. Fomin, K. S. Alabinyan, V. O. and A. O. Vesnin, D. M. Chechulin, F. F. Oliynyk, J. G. Langbard and P. F. Aleshyn, V. M. Rykov, J. A. Shteinberg and V. G. Zabolotny [2, p. 12];

Round III: I. O. Fomin, K. S. Alabinov, S. V. Grigorjev, D. M. Chechulin, and J. G. Langbard (The third round, whose participant works were often attributed to the second one, was discovered by the researcher during the processing of the materials in the archives of the Sofia Kyivska National Reserve, more details are given in other articles of the author [6, 7, 8 etc.]).

Thus, 21 projects of 13 brigades from all over the Soviet Union were presented at the contest, which makes it quite representative in terms of general trends of contemporary Soviet architecture.

The second contest for the restoration of Khreshchatyk, blown up by Soviet undergrounds [9, p. 286], was announced before the end of the World War II, which shows its great ideological and propaganda significance. "June 22, 1944, the Council of People's Commissars of the Ukrainian SSR announced a contest for the planning and development of Khreshchatyk. The initiator of its conduct was 
the current leader of the Communist Party of Ukraine Nikita Khrushchev. The definition of the function of new structures was influenced by political factors ..." [ 10, p. 67].

The first round of the contest was attended by "full members of the Academy of Architecture of the USSR K. Alabyan, G. Golts, the full members of the Academy of Architecture of the Ukrainian SSR P. Alyoshin, O. Vlasov, V. Zabolotny, correspondent members of the Academy of Architects of the USSR V. Gelfreich, E. Levinson, I. Fomin, M. Parusnikov, I. Sobolev, Kyiv architects O. Tatsiy, A. Ivanchenko, prof. Steinberg heading the group of architects in Kiev, an architect from Kharkiv O. Kasyanov and others» [9, p. 286]. Vlasov, Tatsiy and Zabolotny were invited to the second round - the latter refused to participate [9, p. 315].

Consequently, considering the range of outstanding masters, the direct participation of senior party functionaries in the composition of jury commissions, and extensive press coverage, we can assert the approbation of competitive projects of national architectural tendencies, which, according to Khmelnytsky, automatically acquired the force of law and were obligatory for implementation.

Summing up the global similarity of the competition tasks, the environment, the conditions of implementation and the composition of the participants, let us turn to the study of differences. Not having the opportunity to submit an analysis of each of the bids within the same article, we will be inductive to identify the general tendencies that were followed in the contests and their stages.

\section{Regard to existing development.}

Contest for the development of the Governmental Quarter was started with the choice of a plot for future construction. Six principle decisions were developed regarding the location of the future center:

1. The Zvirynets variant, proposed by the architects V. M. Nesterenko and A. Ya. Zinchenko, proposed to place the center on the territory of the former Zvirynetsky fortress, at the highest point on the slopes of the Dnipro.

2. The Pechersk variant of the architects M. I. Grechin, M. Kholostenko and V. M. Onashchenko envisioned a government block on the territory of the racecourse.

3. The Lypky version of the architect P. F. Alyoshin with the team transferred the government area to the crest of the slopes between the modern streets Lypska and Shovkovychna.

4. A variant of the Proletarian (Pioneer) garden by V. I. Zabolotny with the team disclosured Khreshchatyk to the Dnipro. Unfortunately, the perspective solution was not fully appreciated by contemporaries.

5. An option proposed by a group of architects under the direction of V. G. Krichevsky, provided the dispersion of large administrative and public buildings along the uphill part of Kiev.

6. Architects P. G. Yurchenko and Y. Y. Karakis proposed placing the center on the site of the Mykhailivsky Golden-Domed Monastery (first turn) and Government Offices (second turn) [11, p. 53, 54].

The Contest Commission selected a plot on the place of the Mykhailivsky Golden-Domed Monastery, Vasylkivska (Three-Holy) Church, the Square of the Red Heroes of Perekop [12] (now Sophia Square) and the Government Offices. The square should have been 130 meters wide and more than 600 in length [5, p. 2].

The chosen plot caused a lively debate due to the proposal to demolish Mykhailivsky Golden-Domed Monastery. The modern Ukrainian periodical and special press often blames the choice for the architectural and artistic elite of the 1930s, in particular Yosyp Karakis, although his variant was the only one on the designated site, which preserved the cathedral building, with the placement of the building of the Central Committee of the $\mathrm{CP}$ (b) $\mathrm{U}$ on a semicircle, bypassing the temple. The insufficient force of protests and appeals for preservation of the monument is emphasized. However, most historians regard P. P. Postishev as the one who played a decisive role, the second secretary of the Central Committee of the CP (b) U, and, subsequently, the first secretary of the Kyiv regional committee of the party [13], who, ignoring the opinion of experts, influenced the final decision of the commission. 
In the case of the second contest, the pre-destroyed Khreshchatyk street was selected as a building site. All submitted projects did not require significant destruction of the survived structures, in particular leaving the buildings of the Bessarabian market and the Central Department Store, built in prerevolutionary and interwar periods, respectively. That is, in the postwar Kyiv, the setting of the conditions for a contest for the development of a new main artery of the city was much more loyal to historical development, which was completely ignored (and according to the opinion of many researchers, including the author, purposely destroyed) in the previous competition. In our opinion, this was due not only to the financial calculations and to the fact that the site was almost free - in the case of the Governmental quarter, Zvirynets and Lypky variants were also relatively vacant, and were rejected. The Proletarian version partially coincided geographically with the new contest and outstripped its task, offering the disclosure of Khreshchatyk to the Dnipro.

After the tremendous destruction caused by the World War II, the world generally changed its attitude to the historical heritage: large-scale loss of cultural heritage led to the creation of UNESCO as an organization designed to protect and cultivate the heritage of previous eras. Examples of destroyed cities and burnt down historic centers have reinforced the society's demand for the preservation of unique and original buildings.

In our opinion, the corresponding tendency also took place in the USSR, because the state rhetoric of 1941-1942 began an active appeal to the historical past as a means of mobilizing patriotic sentiment. As the confirmation of above there were numerous posters of the time of Moscow's defense, which follows a straight line from the prince's Russia through Peter to the power of that time; the official restoration of the church (and the suspension of the mass destruction of religious buildings), and so on. Despite the revisionist's attitude to the history of the Stalinist regime, in the postwar period, certain elements of the historical past are again "legitimized", to underline, according to the canons of the invented tradition, the connection of a modern regime with previous experience. Appropriate trends also penetrate into architecture, reflected, on the one hand, in a relatively leaner attitude to surviving objects and in the use of "folk» figurativeness and ornamentation on the other, as we will discuss further. Global trends in the growth of the moral value of historic buildings and the crystallization of conservation and museum design approaches in the present form begin precisely in the postwar period. We can see the echo of the relevant tendencies on the example of changing the approach in the contests.

\section{Social and city-forming role.}

The task for a contest in the government quarter contained clear requirements for the houses of the RNK and the Central Committee of the CP (b) U, grouped around a large square for the celebration of parades and demonstrations [5, p. 1]. Most of the task was focused on the square and concomitant facilities:

I. "Place the square near the main city highways and at the same time it should not be transit;

II. The square should have a good connection with the railway and river stations;

III. The square should dominate the city with the disclosure of the ensemble to the Dnipro, with the discovery of its unique topography;

IV. Placement of the square should not cause large demolition of structures (primarily, housing stock);

V. The central square should be located in the most upscale part of the city;

VI. The chosen place of the square should provide the best compositional possibilities in creating an interesting architectural ensemble" [14, p. 16].

A separate place, according to Molokin, since the second round of the contest, was given to the monument to Lenin [2]. Construction of non-administrative, cultural structures was not mentioned. Housing construction was not foreseen.

In the contest in 1944 Khreshchatyk was considered as a street with not only administrative but also cultural buildings - in the projects you can see the city council, the Red Army Theater, the Museum of the Patriotic War, the Post Office and the dwelling. B. S. Cherkes points out that the corresponding multifunctionality had far-reaching goals: "Stalin was in a hurry with the creation of the United Nations and tried 
to get as many places as possible in this organization by introducing his loyal satellites to it. $\langle\ldots\rangle$ Therefore, the task of designing Khreshchatyk was supposed to place here, first of all, the structures of government, representative and public character and thus provide Kyiv with formal features of the capital of the state." [10, p. 67].

D. S. Khmelnytsky in the article "Soviet Town Planning during the War 1941-1945" substantiates and consistently criticizes the very setting of the problem of such contests, states: "The city was considered as a feudal center with impressive architectural ensembles surrounded by indistinct and elemental mass of schematically indicated districts. The 'art of urban planning' was taken to mean the planning of conspicuous ensembles and nothing more" $[15$, p. 329]. In fact, the situation for a city where a large number of people were completely deprived of their roof or lived in a so-called barrier-type temporary housing fund raises a lot of questions. The housing, which was erected on Khreshchatyk, did not solve the problems of the city as a whole, and it was intended primarily for the privileged groups of the population.

However, with all formalism and representative rhetoric, the key change in approach, the departure from a clear division of the city into "quarters": closed government and the rest, which was directly put in the contest in 1934-1935 biennium, cannot be overlooked. The tendency to create a holistic space of the central part, saturated not only with administrative but also with other structures, the gradual transformation of the type of building from the facade on the red line to the dispersed tends to "humanize" the urban space, deploying it to the ordinary urban, which will develop in urbanism from the second half of the 1950s. An example of Khreschatyk blurred the territorial barrier between the "government" and the "public" part of the city, which began to prevail before the war.

\section{Transformation of monumental propaganda.}

After the first round of the contest in 1934-1935, the State Commission noted that "the central monument (monument to Lenin) in all projects did not receive proper significance and expressiveness" [2, p. 13]. Namely, the ruling elite, acting as a customer, prompted masters to change the compositional accents in the direction of monumentalization of the sculpture, as the core of the complex. As noted earlier, starting with the second round, the researchers, O. Molokin, the direct participant of the event, and S. Kilesso, our contemporary, mark the leading role of the monumental approach to the contest task. The customers of the competition, the Central Committee of the $\mathrm{CP}$ (b) U, require, first of all, a figurative solution of the buildings, and architectural tasks only after that. It is necessary "to find comparable and well-specified with the buildings interpretation of the monument, giving it a silhouette and character, corresponding to its value" [2, p. 15].

Fomin and Zabolotny interpret buildings as a peculiar background, a background for a monument of heroic scale. Significant hypertrophy of the sculpture manifests itself in the work of Alabyan - a monument, in fact, dominates in space, shifting the compositional accent. In the projects of Alyoshin, Langbard and Rykov, there is a continuation of the trend of installing a monument on a pedestal column, which is executed accordingly to the general style solution of the complex. The proposal of Chechulin in general transforms the complex of structures of the RNK and the Central Committee of the CP (b) U into a colossal pedestal, a cupboard, a sculptural arch crowned by a monument to the leader. The only project that departed from the general course, one can consider the architect's choice of Oleinik - but his idea was subjected to decisive criticism.

In the contest projects of Khreshchatyk in 1944, the sculpture plays a much smaller role - in all the proposed projects, the authors solve vertical accents due to architectural forms: campanile towers, as G. P. Golts, P. F. Alyoshin or V. I. Zabolotny; obelisks like O. T. Tatsiy or residential development, as O. V. Vlasov. And although the bathos of personality cult is still far away, the tendency towards unpersonalization, the creation of monuments by architectural, and not just sculptural means, the departure from a monument of heroic scale toward multisculptural compositions is directly reflected in urban studies. The transformation caused by global social and psychological shifts in society, where each individual in the practice of war felt the power of the collective, and not a separate leader, reinforced by the rhetoric of 
propaganda about the "nationwide" victory, is directly implemented in changing the approaches of even the formal capital ensembles.

\section{The return of folk motifs.}

The history of the Ukrainian Art Nouveau and Neo-Baroque in the Soviet architecture is surprisingly complex and dramatic. After obtaining free development in the first post-revolutionary years and some state support in the course of the policy of "root-fixing", the National Art Nouveau and Neo-Baroque became the first victims of censorship cleansing and repressions of the mid-1930s. And if some of the master's projects are simply corrected as the V. G. Krichevsky's Shevchenko Museum in Kaniv [16], others with the corresponding projects lose their contests and are criticized for "inconsistency with modern architecture", such as P. F. Alyoshin and V. G. Zabolotny at the contest for the Governmental Quarter, some are repressed and eliminated, accused of bourgeois nationalism, as D. M. Dyachenko. Accordingly, the three stages of the 1934-1935 contest tendentiously show an unofficial ban on the citation of Ukrainian traditional architecture and any national historical variations.

However, a change in the propaganda paradigm during the war and the self-legitimization of the ruling elites through the mythological connection with the historical past leads to a revision of these guidelines, as it has been mentioned before. Along with the marked increase in the moral value of historical achievements against the background of massive destruction, it leads to a revival of interest in folk architecture and the Ukrainian Baroque as a means of architectural and artistic expression and underscores the national and local figurative identity (which, according to Cherkes, also had political motives when the UN was created [10]).

Accordingly, the contest for the reconstruction of Khreshchatyk was a collection of vivid ideas and variations on the topic of Ukrainian motifs, expressed in the citation of baroque or traditional rural architectural forms, as well as in decoration, color scheme, selection of materials for decor. The projects of V. G. Zabolotny and O. O. Tatsiy have been particularly distinguished in it. In the final version, the corresponding trends become more restrained, in the meanwhile, in the widespread use of ceramic decoration of facades with folk motifs, small sculptural plastics and decor. Considering similar projects in other Soviet republics, we can assert the formation of a certain canon of the Soviet post-war neoclassic, which by slightly reducing the heroic scale of elements, allows their national diversity to be identical to the basis of neoclassical forms of structures: a kind of compromise between the interwar Empire style and national variations.

\section{Conclusion}

In complex conditions of the Stalinist dictatorship, creative searches and certain uncertainty, national architectural contests are gaining the leading importance, as a possibility on the one hand, dialogue in artistic circles, and on the other - direct delegation of the will of the ruling elites. Starting from contests for the Palace of Workers in Petrograd in 1919 and the Palace of Labor in Moscow in 1922-1923 [17], open and closed multistage contests define the vector of development and determine the leading accents. Architectural contests were an extremely important phenomenon, which went beyond the choice of a particular project for a specific task it was a place of synthesis, the creation of a new stylistic doctrine and the approval of the development vector in architecture of those years.

Based on the analysis of two contests in Kyiv: Government Quarter in 1934-1935 and reconstruction of Khreshchatyk in 1944, we followed the important tendencies of the gradual transformation in architectural and artistic field under the influence of global social and political changes caused by the World War II.

Trending in the direction of a certain liberalization:

1. The regard of ruling elites to previous development and historical experience as a whole;

2. Social and city-forming role of the central part of the city and reducing the territorial barriers between the elite and the average population. Conditional humanization of the administrative center; 
3. Transformation of monumental propaganda with a gradual departure from the heroic scale and cult of personality;

4. The return of folk and Neo-Baroque motifs to architecture as a means of national identity and creative distinct expressiveness.

Accordingly, the indicated tendencies can be extrapolated to a broad public cultural and artistic field of Kyiv and Ukraine in the mid-1930s - mid-1950's.

\section{References:}

[1] Hobsbawm, E. Introduction: Inventing traditions. [In]: The Invention of tradition. Ed. by E. Hobsbawm \& T. Ranger. Cambridge.: Cambridge University Press., 1992.

[2] Molokin A.: Architecture Of The USSR, 1935, 9, 11.

[3] Bylinkin N Architecture Of The USSR, 1945, 11, 1.

[4] Socialistic Kyiv, 1934, 1-2, 1.

[5] Socialistic Kyiv, 1934, 3-4, 1.

[6] Markovskyi A.: Urban Planning And Theoretical Planning, 2014, 51, 337.

[7] Abyzov V,. Markovskyi A.: Srodowisko Mieszkaniowe [Housing Environment], 2015, 14, 94.

[8] Markovskyi A.: Architectural Bulletin of Kyiv National University of Construction and Architecture, 2014, 3, 56.

[9] Erofaloff-Pilipchak B.: Architecture of Soviet Kiev. A+C, Kyiv, 2010.

[10] Cherkes B.: National identity in the architecture of the city. Lviv Polytechnic, Lviv, 2008.

[11] Kilesso S.: Design of the Kiev center in the prewar period [in] Kiev architecture. Kyiv, 1982.

[12] Protocol of the meeting of the Kiev Provincial Committee of December 27, 1920 No. 95-a, p. 1 "On renaming a street or square in the city in memory of those killed at Perekop". State Archives of the Kiev Region. F. P-1, op. 2, Ref. 9, arc. 99.

[13] Gevrik T.: Lost architectural monuments of Kyiv, New York, 1987.

[14] Yurchenko P.: Socialistic Kyiv, 1936, 5-6, 14.

[15] Chmelnizki D.: Soviet Town Planning during the War, 1941-1945 [In]: A Blessing in Disguise. War and Town Planning in Europe 1940-1945". Jorn Düwel/ Niels Gutschow Eds. Dom publishers, Berlin, 2013.

[16] Markovskyi A.: Modern Problems of Architecture and Urban Development, 2014, 35, 159.

[17] Ryabushin A., Shishkina I.: Soviet architecture M. : Stroiizdat, Moscow, 1984.

Андрій Марковський

\section{ТРАНСФОРМАЦІЯ ПАРАДИГМ У КОНКУРСАХ НА ЗАБУДОВУ ЦЕНТРУ КИСВА 30-40-х pp. ХХ ст.}

\footnotetext{
Анотація. У статті досліджено трансформації архітектурно-мистецького поля України 1930-1940-х років та далі до середини 1950-х, під впливом зовнішніх факторів, зумовлених Другою світовою війною. За основу пошуків прийнято матеріали двох провідних конкурсів: на забудову урядового кварталу 1934-1935 років та відбудову Хрещатику 1944 року, як найбільи тенденційні та представницькі події у Киїській архітектурі періодів “до» та “після» війни в означеному хронологічному інтервалі.

У складних умовах сталінської диктатури, творчих пошуків та певної невизначеності, провідного значення набувають загальнодержавні архітектурні конкурси, як можливість з одного боку, діалогу у мистецьких колах, а з іншого - прямого делегування волі правлячих еліт. Починаючи від завдань на Палач робітників у Петрограді 1919 р. та Палач прачі у Москві 1922-1923 рр., відкриті та закриті багатоетапні конкурси задавали вектор розвитку, визначали провідні акценти радянської архітектури та були надзвичайно важливим явищем, шуо виходило за межі вибору того чи іншого проекту під конкретне завдання - це було місие синтезу, створення нової стилістичної доктрини та затвердження вектору розвитку архітектури тих років.

Дослідником взято за основу загальну подібність умов поля, в яких існувало архітектурно-мистецьке життя Києва 30-х і 40-х років ХХ ст.: підсилення вертикалі імперської влади, держзамовлення, репресії та декларування ідей правлячих еліт напряму через засоби монументальної пропаганди. Також враховані ідентичність матеріально-технічних можливостей та подібний склад учасників. Тим часом відслідковується низка важливих закономірностей поступової трансформачї поля під впливом глобальних сочуіолотичних зрущень, спричинених Другою світовою війною.
} 
Тенденційно трансформуються у бік певної лібералізації:

1. Ставлення правлячих еліт до попередньої забудови та історичного досвіду загалом;

2. Соціально-містоформувальна роль центральної частини міста та зменшення територіальних бар'єрів між елітою та пересічним населенням. Умовна гуманізація адміністративного иентру;

3. Трансформачія монументальної пропаганди з поступовим відходом від героїзованого масштабу та культу особистості:

4. Повернення народних та необарокових мотивів в архітектуру як засіб національної ідентифікації та творчої самобутньої виразності.

Відповідно, означені тенденції можуть бути за допомогою індуктивного методу екстрапольовані на широкий загал культурно-мистещького поля Києва та Украйни середини 30-40-х років XX cm. (i далі до середини 50-х рр. ХХ ст.).

Ключові слова: архітектура Києва, конкурс, урядовий квартал, Хрещуатик, трансформація парадигм. 